\title{
Financial Transition in Pre-World War II Japan and Southeast Asia*
}

\author{
Gregg Huff \\ Department of Economics, University of Glasgow, Glasgow G12 8RT Scotland \\ Fax: ++ 441413304940 \\ E-mail:w.g.huff@socsci.gla.ac.uk
}

\begin{abstract}
This article compares Japan and Southeast Asia before the Second World War to explore the question Goldsmith posed: why, since financial transition in all countries follows the same path, should there be such remarkable differences in the speed of transition? Beginning after the Meiji Restoration in 1868 and starting from the same per capita income as Southeast Asian countries, Japan had, by 1913, built a modern financial system comparable to those in the West. But finance in Southeast Asian countries was (and remained in 1939) little developed, dominated by metropolitan interests, heavily reliant on informal finance, and geared towards primary commodity exports. The article argues that Southeast Asia's no more than partial financial transition is explained by a continued ability to tap natural resources, limited technological change, and the laissez-faire stance of colonial governments. Japan, by contrast, could not depend on abundant resources for growth. Its experience demonstrates how nationalist objectives of military power and industrialisation can motivate government to accelerate financial transition.
\end{abstract}

* An earlier version of this article was presented at the 2003 Economic History Association Meeting in Nashville. Thanks go to conference participants for many helpful comments and suggestions and to Andrew Bain, Michael Edelstein, Tim Guinnane, Janet Hunter, Joel Mokyr, Larry Neal, and Dick Sylla. Thanks also to the editor and two anonymous referees for a number of useful ideas and clarifications which considerably improved the article. Support for research and data collection provided by the Nuffield Foundation, the Carnegie Trust, Scotland, and the British Academy is gratefully acknowledged. 


\section{Financial Transition in Pre-World War II Japan and Southeast Asia}

Self-sustaining, technologically-based growth has always been accompanied by a process of financial transition which, as defined by Raymond Goldsmith, entails an increase in the financial superstructure to a status in the economy comparable to that in the leading countries of North America and Western Europe. ${ }^{1}$ The pattern of development along this transitional path may, of course, differ, as for example in the relative contribution of bank- or market-based financial systems. But all countries, Goldsmith observed, trace a similar transitional path in the increase in their superstructure of financial instruments and institutions relative to an infrastructure of output and wealth. Because of the close relationship between financial transition and modern economic growth as defined by Simon Kuznets, differences in speed at which countries traverse Goldsmith’s transitional path are critical.

In 1870, ‘a percipient and knowledgeable economist’ like Mill or Marx, Goldsmith argued, would have expected India to progress further along the path of financial transition than Japan. 'Neither Mill nor Marx would ever have envisaged the abysmal difference' in transitional speeds, and therefore financial development, that over subsequent decades increasingly differentiated the two countries. ${ }^{2}$ For many of the reasons that Goldsmith cited as relevant to the India-Japan comparison, it might also have been anticipated in 1870 that Southeast Asian countries would move as quickly as Japan towards financial transition. Japan and the six Southeast Asian countries of Burma, Thailand, Malaya, Indonesia, Indochina and the Philippines were all poor, overwhelmingly agrarian economies with similar per capita incomes and sectoral distributions of output and labour force. Indeed, in some respects Southeast Asian countries might have been thought in 1870 the more likely to accomplish financial transition and an associated process of economic development. The 1868 Meiji Restoration only just completed, Japan was still politically unstable, whereas Southeast Asia already had, or was about to acquire, the stability and strong legal framework associated 
with colonial rule. Although Southeast Asian countries, as Goldsmith noted of Japan, lacked 'modern financial institutions' they had, like Japan, a framework of European banks. ${ }^{3}$ Southeast Asia's links with the West might have been expected to give access to capital and technology. While Japan had the more developed tradition of indigenous industry, Southeast Asia possessed a far greater abundance of natural resources. Yet by 1913 Japan had a modern financial system and ranked in the same class as Western countries. No Southeast Asian country reached a point comparable to Japan in 1913 until well after the Second World War.

A large body of work considers the causal relationship between financial and economic development, ${ }^{4}$ and Rajan and Zingales show how interest groups can reverse financial development. ${ }^{5}$ It is suggested that major strands of causality, perhaps even the dominant ones, run from financial to economic development. But the literature remains largely silent on the question posed by Goldsmith: why are differences in the speed at which countries move along a transitional path of finance so great? Even Goldsmith, although asking that question, immediately concluded that: 'Needless to say, an answer will not be forthcoming'. ${ }^{6}$

This article aims, first, to contribute to an answer to Goldsmith's question by comparing Southeast Asian and Japanese financial development, and, second, to increase understanding of Southeast Asian financial experience. ${ }^{7}$ What might have happened in Southeast Asia, and what did happen, can only be fully understood through what did not happen. That is not to say that Japan is a norm or model which, in some better world, Southeast Asian countries might have followed. Rather it is to argue that Southeast Asian countries were, a few crucial parameters apart, not so different from Japan. Identification and assessment of the relative importance of these parameters affords insight into the factors which govern speeds of financial transition.

I argue that, in part, different needs for finance arose from opposite factor endowments. From the start a bias existed towards divergent financial development in Southeast Asia and Japan. The article contends, furthermore, that political organisation and social goals are 
fundamental in explaining the economics of transition. In Southeast Asian countries, relatively undeveloped political and social structures and a lack of national identity restricted resistance to

nineteenth-century Western expansionism. A resulting extension of colonialism severely limited the possibility of financial transition. Japan, however, was sufficiently socially and politically unified to respond to foreign intrusion with a strong nationalism and drive towards military power, industrialisation and modern finance.

The history of financial transition in Japan is sometimes written in terms of a great-man theory, the great man being Count Masayoshi Matsukata. In Southeast Asia, colonial rule effectively precluded the emergence of 'great men' to effect financial transition. Even supposing, however, that six such individuals had existed, one for each Southeast Asian country, the article suggests that they would have remained in obscurity: the environment of an emergence of a modern state and modern economic growth which complement financial transition and allow great men to act was lacking.

This article is structured in six sections. The first considers some of the principal features of economic growth and development in Southeast Asia and Japan. Four further sections analyze and compare Japanese and Southeast Asian experiences of financial development and transition. The last section compares Southeast Asia and Japan in light of an analytical framework pioneered by Richard Sylla and attempts to identify the reasons for differing transitional speeds. ${ }^{8}$

\section{Growth and Change in Southeast Asia and Japan}

Between 1870 and the Second World War, economic growth in both Southeast Asia and Japan was substantial but took quite different courses. As striking were the opposite effects on Japan and Southeast Asia of foreign intervention. This section analyzes contrasting Southeast Asian and Japanese development patterns.

In 1850, little of Southeast Asia, except Java, some other parts of Indonesia, and the 
Philippines, then still ruled by Spain, was under European control. Societies in Southeast Asia were, however, too traditional, too technologically backward and too fragmented to repel or negotiate effectively with foreigners. By the 1880s, when Japan had fulfilled the 'politically essential preconditions' for transition to a modern state, ${ }^{9}$ most of Southeast Asia was divided into spheres of Western influence or had fallen under colonial rule. At the turn of the century, Southeast Asia was governed by four colonial powers — Britain (Burma and Malaya); the Netherlands (Indonesia); France (Indochina); and the United States (the Philippines). Thailand (Siam), nominally independent, had quasi-colonial arrangements and a British financial advisor. After 1870, growth in Southeast Asia stemmed predominantly from international trade that afforded a 'vent' or outlet to utilize surplus land in the production of primary commodities which, unless exported, would not have been worth the effort of producing. However, in parts of Southeast Asia, including Java, north Vietnam in Indochina, and central Luzon in the Philippines, dense population ruled out vent-for-surplus growth. Prominent in the venting of surpluses was dependence on a few staple exports. Burma, Thailand and Indochina all relied heavily on rice, the Philippines on sugar, and both Malaya and Indonesia (in its so-called Outer Provinces beyond the Javanese centre) on tin and rubber.

Vent-for-surplus agricultural output in Southeast Asia divided between small farmers and estates, predominantly European-owned. Before about 1910 estates had significance only in parts of Indonesia and the Philippines, while small Chinese enterprises produced most of Malaya's tin. Subsequently, large-scale units gained in prominence. But even in the inter-war years small farmers produced the bulk of Southeast Asian exports.

In Japan, the arrival of Commodore Perry's squadron in Edo (Tokyo) Bay in 1853 and again in 1854 closely paralleled the timing of Western expansionism in Southeast Asia. Japan was forced to open itself to trade, grant treaty port concessions, and accept 'semi-colonial' status until the 1880s. ${ }^{10}$ But, despite the several similarities, Japan had initial conditions superior to 
Southeast Asia’s. By the mid-nineteenth century, population had for some time remained stable. Although some $80 \%$ of Japan's labour force engaged in farming, Edo, Kyoto and Osaka were large cities. Crafts and trade were significant activities and, more important, spread fairly evenly through Japan. There was already a well developed, if traditional, financial system. ${ }^{11}$

Japan's remarkable homogeneity of culture and language, when harnessed by the Meiji Restoration, powerfully promoted a 'burst of enthusiasm for national goals'. ${ }^{2}$ 'Ideas of modernity — progress, science, and rationality — meant a great deal to the Japanese people', most of whom looked to the state to initiate change. ${ }^{13}$ The conservative oligarchy that gained legitimacy in Meiji Japan viewed international relations as a 'single alternative: conquer or be conquered'. ${ }^{14}$ To avoid the latter required economic 'catch up' and the creation of a modern state like those which emerged in nineteenth-century Western Europe and the United States. ${ }^{15}$ Fundamental to these political and economic objectives was the development of modern financial institutions.

An identification of industrialisation and financial development with nationalism and the military power necessary to respond to Western intrusion directed growth in Japan along a path different to Southeast Asia's. So too did Japan's factor endowment of labour, not resource, abundance. In 1881 population density in Japan was 271 persons per square mile compared to 25 to 53 persons in Southeast Asian countries excepting Java. To grow economically, Japan had to rely on technical change and structural transformation. At first, the dominant force in Japanese growth was indigenous or so-called Meiji technology. Between 1870 and 1900 its spread decisively raised agricultural productivity. ${ }^{16}$ Silk filature and Japan's first modern industry, cotton goods manufacture, expanded rapidly. Even so, in 1905 manufacturing and mining together comprised only $12 \%$ of Japan's GDP, compared to agriculture's $26 \%{ }^{17}$

In the 1920s the focus of Japanese technological development moved towards heavier, capital intensive industry such as chemicals, iron and steel, machinery and electrical 
equipment. ${ }^{18}$ 'Post-textile' technology was accompanied by profound structural change that shifted resources into faster growing sectors than agriculture and continuously afforded opportunities to adopt and finance new technology. By 1939 manufacturing and mining accounted for $34 \%$ of GDP and agriculture for just $15 \% .^{19}$

War and Imperialism had major developmental implications for both Southeast Asia and Japan. For Japan, the Sino-Japanese War of 1894-95 and the Russo-Japanese War of 1904-5 were, in cost-benefit terms, among modern history's 'most effective political and economical military operations ${ }^{20}$ and important both to financial development and industrialisation. War indemnity from China enabled Japan to join the international gold standard in 1897 and so borrow in London to finance the Russo-Japanese conflict. The consequent benefits of enhanced international standing and 'the possibility of exploiting China' exceeded even those of the 189495 war. $^{21}$ Southeast Asian countries were, by contrast, the vanquished not the victors of late nineteenth-century imperial aggression.

By 1886, Japan had begun modern economic growth. ${ }^{22}$ To be sure, from the 1870 s onwards Southeast Asian countries - like Japan — acquired extensive infrastructure such as roads, harbours, electric power, telegraphs and telephones. In Southeast Asia technical progress also occurred in tin mining, petroleum extraction, the processing of primary commodity exports and merchant activities. But vent-for-surplus agricultural staples in inter-war Southeast Asia were grown employing much the same technologies as had been used decades previously. The lack of technical change in agriculture and a failure fully to accomplish the first or 'easy' stage of import-substituting industrialisation mark out Southeast Asia as falling short of modern economic growth. ${ }^{23}$

Existing statistics indicate that in 1870 most Southeast Asian countries stood at approximately the same level of GDP per capita as Japan (table 1 ). ${ }^{24}$ For Southeast Asia and Japan during the twentieth century two available sets of per capita GDP estimates permit 
divergent conclusions. One set (panel a) shows that by 1913, and even more in 1929, Southeast Asian countries, other than Malaya at the later date, had fallen distinctly behind Japan. These figures suggest that 1929 per capita income in Malaya including Singapore was about 12\% less than in Japan. The other, yen-based data set (panel b) indicate that in 1913 Southeast Asian incomes were still equal to Japan's. These data find inter-war per capita income in Malaya well ahead of Japanese levels but other Southeast Asian countries considerably behind them. The 1930s collapse in the world economy largely ended growth in Southeast Asia, though not in Japan.

\section{Monetization, currency boards and central banks}

In Southeast Asia, whenever possible financial development was left to the market. The Japanese government, typically looking abroad for prototypes, was instrumental in the creation of modern financial institutions as part of the Meiji drive to modernization. This section, and the three which follow, compare Southeast Asian and Japanese financial development and raise two main issues concerning financial transition. How did contrasting approaches to finance by governments in Southeast Asia and Japan affect transition? And how did finance facilitate, and to what extent was it shaped by, divergent development paths in Southeast Asia and Japan?

In 1870, neither Japan nor any country in Southeast Asia had a unified monetary standard. At the time of the Meiji Restoration, Han (feudal clan) notes were in circulation and by March 1870 the government had already issued 20 proclamations to try to resolve a currency system described as 'chaotic'. ${ }^{25}$ The Mexican dollar, as in Southeast Asia, served in early Meiji Japan as the currency for international payments. ${ }^{26}$

During the late nineteenth century Southeast Asia's monetary systems became increasingly uncertain and piecemeal due to a progressive breakdown in the silver standard, and so also in the use of the Mexican dollar for domestic as well as international payments. Southeast Asian governments were forced into regulation. A near-universal solution was the 
adoption of the gold-exchange standard, by Indonesia in 1891, and within seventeen years by all but one of the other countries: Indochina remained on silver until 1930 and had more flexible monetary arrangements than elsewhere in Southeast Asia. ${ }^{27}$ The gold-exchange standard incorporated colonial currencies into the international gold standard by tying them, rather than directly to gold, to the gold-based currencies of the ruling country (for Siam, Britain) at a fixed exchange rate. Because the link to gold was through the metropolitan currency, the system could be described variously as the sterling-, dollar- or guilder-exchange standard. ${ }^{28}$

Southeast Asian gold-exchange standard currencies were comprehensively backed by foreign reserves, typically in the currency of the ruling country. The backing was usually $110 \%$ in British colonies (and Siam), where colonial currency boards were established (operative in Siam through the Treasury) to issue local currency in exchange for equivalent foreign reserves. Similar backing obtained in India, of which Burma was a province until 1937, where three Presidency banks (from 1921-1934 the Imperial Bank of India) acted like a currency board. ${ }^{29}$ In Indonesia the government gave a private bank, the Java Bank, the exclusive right to issue currency, subject to a high reserve backing. The Bank safeguarded exchange rate fixity with the Dutch guilder through discount policy but, like currency boards, could not control Indonesia's domestic monetary policy. ${ }^{30}$ The new Southeast Asian colonial currencies — under a currency board, or currency-board-like, system identical to metropolitan currency apart from the printing on the notes — quickly gained credibility. Unified systems of money spread rapidly throughout the region. ${ }^{31}$

After the Meiji Restoration a swift modernization of Japan's monetary system might seem a near precondition for speedy financial transition. Instead, the establishment of the yen as a national currency convertible into specie was lengthy process and depended on extensive government involvement to build a modern banking system and stabilise the yen. Two government attempts soon after the Restoration to encourage the development of a banking 
system failed. A major stumbling block was public distrust of paper money combined with the convertibility of bank notes into silver, which made it difficult to keep the paper in circulation. ${ }^{32}$ In its third attempt, the government imaginatively created a banking system while at the same time finding an alternative to the great burden on the exchequer of pensions which had been paid to feudal lords (daimyo, numbering less than 300) and their sumurai, or warrior, retainers. The pensions had been given after an 1873 Meiji land tax replaced feudal in-kind levies on the rice harvest. By 1876 the pensions had been commuted to government bonds. The National Bank Act of 1876 allowed the commutation bonds to be used to capitalise banks; bank notes ceased to be convertible into specie, and greater profit margins for banks increased the incentive to enter banking. Just four national banks existed in 1876, but by 1879 these numbered 151 and extended to most parts of Japan. Samurai and the nobility, mostly ex-daimyo, held $75 \%$ of the stock of national banks. ${ }^{33}$ Most deposits in the new banks were the government's. Even at the end of the 1870s, however, Japan's monetary system remained unstable, fragmented, and subject to serious inflation.

Count Matsukata, appointed finance minister in 1881 and the architect of the financial system as it developed over the next three decades, immediately adopted strict monetarist orthodoxy and began a far-reaching programme of institution building. He used the Belgian central bank and pre-1914 German Reichsbank as models to found the Bank of Japan in 1882. Between 1881 and 1885 Matsukata engineered savage money supply contraction and deflation, and used a sweeping privatisation of state-owned enterprises to reduce government liabilities. By 1886 Japan had stable public and private finance. A network of commercial banks existed and the Bank of Japan began effectively to assume the functions of a central bank. Its notes, convertible into specie, started to replace inconvertible paper money and by 1897 comprised three quarters of money supply.

The Bank of Japan resembled the Reichsbank in its elastic issue system, which allowed 
notes to be issued well in excess of gold reserves. By contrast, colonial monetary arrangements amounted to an extreme version of the classical gold standard. A loss in foreign reserves, for example arising from a slump in foreign demand and fall in the value of exports relative to imports, necessitated an immediate and automatic contraction in local money supply. Monetary contraction reinforced the initial contraction from a decline in exports and, in the event of a sharp initial downturn, led to a bank liquidity crisis. ${ }^{34}$ Unlike a central bank, currency boards, such as those in Southeast Asia and the Java Bank, minimise government involvement and cannot act as a lender of last resort to commercial banks or attempt to stabilize the economy.

\section{Banking development}

In developing countries the financial system can be described as dual if most of the economy relies on informal or pre-modern finance, and if this finance is largely separate from a relatively small modern financial sector. A test for financial transition is the extent to which elements of dualism are continuously eliminated as countries develop a unified modern financial system that expands at the expense of informal finance. One theme of this section is the financial dualism characteristic of Southeast Asia compared to Japan's progressive unification in the market for finance. A second, related theme is how government can accelerate — or frustrate — financial transition. The two themes of market segmentation and the role of government are discussed in this and in subsequent sections on long-term and rural finance.

Japanese banking in the 1860s paralleled Southeast Asia's in that a number of major European (chiefly British) banks opened branches to finance foreign trade. Thereafter, however, while in Southeast Asia formal finance continued to be dominated by a handful of European branch banks, finance rapidly evolved in Japan. The main change in Southeast Asia was the emergence after 1900 of a distinct tier of local Asian banks that competed little, if at all, with European banks, thus preserving a clearly segmented financial structure.

In the nationalist and modernizing climate of Meiji Japan, reliance for finance on an 
1860s 'western banking invasion' (also prominent in Southeast Asia) and local quasi-banks, engaged in moneylending and a variety of financial activities, was never acceptable. ${ }^{35}$ Instead, Japan's government-led development of finance centered on creating a modern banking system. Subsidies to develop bank finance as an infant industry came in three ways: through the right of national banks to issue notes at zero cost; through government deposits in national and private banks; and through the government's use of these banks to carry out a number of its fiscal activities. After a mid-1890s withdrawal of the note-issuing privileges of national banks, the Bank of Japan was the sole issuer of bank notes. ${ }^{36}$

Between 1900 and 1913 Japanese banks (now a single system of so-called ordinary banks after the expiration of national bank charters) evolved into true financial intermediaries: half of their funds came from deposits whereas in 1870 banks had mainly lent their own funds. ${ }^{37}$ In 1910 the five largest banks — Mitsui, Mitsubishi, Sumitomo, Yasuda (Fuji after 1945) and Daiichi — accounted for over a fifth of all commercial bank deposits. Already alliances of all of the five largest banks with zaibatsu (family conglomerates) set a pattern of bank concentration and industrial finance important to subsequent Japanese industrialisation. ${ }^{38}$

In Japan a development-oriented nationalism and an effective government bureaucracy which promoted modern finance infused financial development with a dynamism largely absent in Southeast Asia. Japan's route to currency unification based on the yen might seem unnecessarily protracted compared to Southeast Asia's swift and successful introduction of unified currencies. But Japan's approach had the strong advantages — consistent with the 'finance-led' growth Rousseau and Sylla find for the United States and Rousseau for Japan ${ }^{39}$ of rapidly building an integrated financial network which promoted the economy's structural transformation from agriculture towards industry, and especially during the inter-war years to heavy and chemical industries. ${ }^{40}$ Monetary flexibility of a kind impossible under colonial currency boards enabled the Japanese government to oversee the banking system, to mitigate 
banking instability in the 1920s, and, through Japan's banks, to direct resources towards economic modernization. ${ }^{41}$

At the turn of the century in Southeast Asia, formal finance (as in Japan just before the Meiji Restoration) still consisted chiefly of European branch banks. These, characteristically with head offices in metropolitan countries, restricted themselves almost entirely to financing the region's trade with Western countries and, due to this orientation and associated currency dealings, became known as 'exchange banks'. Three main British banks — the Hongkong and Shanghai Banking Corporation, the Chartered Bank of India, Australia and China and the Mercantile Bank of India — operated throughout Southeast Asia. Even in non-British colonies these banks financed much of trade and exercised a degree of monopoly power. ${ }^{42}$ Other exchange banks in Southeast Asia — the Banque de l'Indochine, the Java Bank, the Netherlands Trading Society and the National City Bank of New York — were less international than their British counterparts.

Before the Second World War, European, and especially British, banking in Southeast Asia ventured little beyond its nineteenth-century exchange bank origins. Unlike Matsukata's planned structure of complementary finance, Southeast Asia's oligopolistic banking structure, within which banks remained largely unwilling to lend outside the foreign trade sector, circumscribed the local availability of finance for entrepreneurs. ${ }^{43}$ European banks lent (typically through compradores when dealing with Chinese) to only a comparatively small number of important Asians. ${ }^{44}$

Under Matsukata prominent features of Japanese banking development were functional specialization, government incentives to develop institutional finance and, directed by the government, banks' support of one another.. Some of the so-called special banks for which he planned are discussed later in the context of long-term finance. But one special bank, the Yokohama Specie Bank dating from 1880, is dealt with here because of the contrast with 
Southeast Asia. The Bank, soon an adjunct of the Bank of Japan, was a direct government response to the Western exchange bank monopoly in financing Japanese trade. ${ }^{45}$ By 1911 the Specie Bank financed 45\% of Japan's foreign trade compared to the Hongkong and Shanghai Bank's 30\%. The Specie Bank was afforded capital and preferential interest rates by the Bank of Japan and, in subsidizing export industries, became a vehicle for Japanese industrial policy. ${ }^{46}$

After 1900, a tier of indigenous banking emerged in Southeast Asia through local Asian banks in major urban areas including Singapore, Penang, Rangoon, Bangkok, Saigon and Manila. Unlike European banks, they were willing to lend widely to local Asian entrepreneurs and industrialists and tapped a different, broader market for deposits and savings than European banks. In Singapore, for example, Asian banks encouraged the 'banking habit' and mobilized additional finance, since even in the inter-war period 'the European banks had an air about them which intimidated many local people ... [and] would not accept small accounts'. ${ }^{47}$ Similarly attractive to local Asians were two Chinese banks established in Manila in the 1920s, while in Rangoon a variety of Indian and Chinese banks served the local Asian community. ${ }^{48}$

It was virtually certain, however, that in Southeast Asia local Asian banks would remain small because of colonial currency board or currency board-like systems and heavy reliance on a narrow range of primary commodities subject to high volatility. Any export slump and consequent balance of payments deficit left the Asian banking sector highly vulnerable to insolvency for three reasons. Unlike Japan, Southeast Asia had no central banks to serve as lender of last resort; there were rigid, not elastic, note issue systems; and Asian banks had no access to an external wholesale credit market. Asian banks faced uncertainty over the timing and extent of export, and consequent monetary, contractions. These, in turn, led to a cash drain and the danger of a liquidity crisis. That uncertainty, and the absence of recourse to a central bank or a metropolitan head office like European banks, seriously curtailed the scope of Asian banks for lending and so their allocative role for finance. As a response to uncertainty, Asian 
banks normally kept at least $50 \%$ of current account deposits liquid by depositing them with European banks. $^{49}$

Few financial statistics exist for Southeast Asia. But those available show two main differences in the pace and extent of Southeast Asian and Japanese financial transition. First, monetization in Southeast Asia lagged Japan in 1913. Nevertheless, it was well underway and caught up during the inter-years. Between 1913 and 1938 throughout Southeast Asia M0 per capita rose rapidly, approximately doubling on average (table 2, panel a). High M0 per capita in Malaya reflected a degree of economic specialization exceptional even among Southeast Asia's vent-for-surplus economies.

Second, the obvious gulf between Southeast Asia and Japan was in banking development and so financial depth. Since M1 differs from M0 essentially in the inclusion of checking account money created by the banking system as a result of deposits, the larger the difference between M1 and M0 the greater the scope for banks to mobilize finance for economic development. Similarly, M2 adds to M1 by including time or savings deposits and so indicates a further increase in financial depth through the banking system's role in allocating more (and probably also longer-term) finance. In Japan in 1885 the banking system still did little to mobilize finance: the ratios of M0/GDP and M2/GDP were almost identical. But by 1913 the ratio M2/GDP was over five times that of M0/GDP and similar to the United States' ratio (table 2, panel c). By contrast, the small differences between M1 and M0 in Southeast Asia show the restricted role of banks and indicate still shallow finance. In 1938 Southeast Asian ratios of demand deposits to M0 were around 0.33 to at most 1.0 compared to about 2.1 in Japan and 4.5 in the United States (table 2, panel a). Moreover, in 1938 M2/GDP ratios in most Southeast Asian countries still fell short of Japan's financial depth by 1900 (table 2, panels b and c).

Statistics for bank assets tell much the same story as monetary data (table 3). By 1938 Southeast Asia was well behind Japan, both in terms of bank assets relative to GNP and per 
capita assets. Malaya was again apparently the most financially advanced Southeast Asian country but because no statistics for it exist until 1949 comparison is approximate. A higher assets/GNP ratio in Japan than the United States reflects the large role of the banking system in Japanese financial development.

\section{Long-term finance}

The banks established in Japan after 1870 were ill suited to the provision of long-term finance, but by, in effect, providing this were important to industrialisation. It has been said that banks were 'decisive' in the development of the railway, cotton spinning, and silk reeling industries. ${ }^{50}$ But long-term finance in late nineteenth-century Japan also depended on the availability of stock markets and, crucially, on government support for the banks. This section considers four issues. It first discusses stock market development in Japan and Southeast Asia. Second, an analysis of railway finance shows the complementary relationship between the private sector and Meiji government. Third, the Japanese government's establishment of institutions for long-term finance is considered. Fourth, the section analyzes long-term finance in Southeast Asia.

In 1878 stock exchanges, modeled on European markets, began in Tokyo and Osaka. The Tokyo Exchange, established to afford ex-samurai bondholders an outlet for their money, soon grew into the premier of a multiplicity (46 by 1898) of new exchanges set up, with government encouragement, throughout Japan. In 1890 only 1\% of Japan’s 4,300 joint stock companies were listed on the Tokyo Exchange. But they were all 'first rate big companies playing major roles in the new industrialisation' and included representatives of the three main industries of railways, cotton spinning and electric power. ${ }^{51}$ Between 1897 and 1911 market capitalisation of the Tokyo Exchange grew from $¥ 564$ million to ¥2,095 million and considerably faster than GDP. In 1912 the Japanese ratio of corporate stock to GDP of 0.41 compared to 0.95 in the United States and 1.21 in the United Kingdom. ${ }^{52}$ By contrast, even in the 1920s and 1930s local Southeast Asia exchanges were at best rudimentary. These included 
the Manila Stock Exchange, which traded mostly in mining shares, and the Rangoon Stock Exchange. Only in the 1960s did equity markets began seriously to add to Southeast Asia's financial landscape. ${ }^{53}$

Nineteenth century railway building in developing areas was typically financed through foreign investment, mainly from Britain. Japan was at first no different: in 1870 the Meiji government borrowed in London for a railway linking Tokyo and the port of Yokohama. ${ }^{54}$ But soon Meiji policy eschewed foreign borrowing. ${ }^{55}$ Instead, government turned to private national finance and supported it strongly with state resources. Private railway companies accounted for over two-thirds of the rail network of 7,725 kilometers by 1905, and $80 \%$ of their capital had been raised through stock issues. Much of this capital came through effectively long-term finance from banks, both because of bank lending to finance the purchase of railway shares against these as collateral, and because of banks' substantial railway shareholdings. Starting in 1885 the Bank of Japan, contrary to its stated rules as a central bank, underwrote long-term bank finance for railways through advancing to banks against the collateral of railway shares.

Finance for railway development was mobilized through a system of interconnected incentives. The banks could attract funds by offering private depositors a comparatively safe fixed return, while railway shareowners, borrowing from banks to finance stock purchases, anticipated dividends above bank interest rates. A dominance of 'dividend-seeking investors' insistent on the distribution of almost all railway company profits reflected their need to finance bank loans. ${ }^{56}$ The Tokyo and Osaka stock exchanges afforded investors both liquidity and an institution through which, if railway stock appreciated, shares could be sold and a capital gain realized.

The relationship forged around railway development in Japan was not just between railways and banks nor between railways and stock markets alone. Rather there was a synergy between individual shareholders, the banks as lenders and as railway shareholders, stock 
markets and the government. Use by banks of short-term private deposits to finance long-term railway stock loans was risky. Risk mounted as railway stock became a sizeable proportion of bank assets. ${ }^{57}$ The Bank of Japan responded to an 1890 collapse in the value of railway stock by adding to the list of railway company shares it accepted as collateral and by enlarging for railway shares its 'last resort' or special discount system. Until nationalization of the rail network in 1906, the Bank of Japan remained the ultimate bearer of railway stock collateral loans. ${ }^{58}$ This role of government acting through the Bank of Japan — a relationship underplayed by Miwa and Ramseyer in their emphasis on the importance of stock markets was crucial, not just to railways but also to other industries. ${ }^{59}$ Through special discounting to banks, the Bank of Japan 'could extend its support to securities markets, which would then inevitably come to rely heavily upon the Bank in the new century, ${ }^{60}$

Railway nationalization in 1906-7, effected by issuing public bonds in exchange for railway shares, freed and re-directed the large amount of private capital tied up in railways into other long-term investment. Compensation for nationalization was paid at about twice railway construction costs. ${ }^{61}$ The Meiji state used railway nationalization to substitute for private financial intermediation. Funds that the government mobilized from a wider domestic and international public were put, as part of nationalization, in the hands of entrepreneurs likely to undertake productive, long-term investment. Former railway shareholders who sold the nationalization bonds would not, the Finance Minister explained, use the money for 'eating and drinking sake. I am sure they are bound to set up spinning and shipping companies in Japan or invest willingly in such enterprises in Manchuria and Korea'. ${ }^{62}$ And, in fact, one-time Japanese railway capitalists, drawing on the highly liquid public bonds as capital and collateral, invested heavily in the iron and steel industry, light railways, tramways, and gas and electric power companies. Among others, Mitsubishi 'profited enormously' from railway nationalization and used this capital injection to invest in shipbuilding and mining and branch into several new 
industries. $^{63}$

One source of state funds for railway nationalization was a postal savings system set up by the government in 1875. Like post office banks in United Kingdom-ruled Southeast Asian colonies, postal saving arrangements in Japan derived from Gladstone's British model. But Meiji Japan, under Matsukata's urging, mandated that the postal savings 'concentrate funds from the hands of the people for modernization'. ${ }^{64}$ Postal savings, in 1919 equivalent to $13 \%$ of total banking deposits, became for the government 'a huge, opaque pool for various policy lending purposes'. $^{65}$

The late nineteenth-century interrelationship between the Japanese state and a financial system which (the stock market apart) was not suited to long-term investment was an ingenious makeshift. Meiji Japan recognized, however, the need for institutions specifically designed to provide long-term finance. Special long-term credit, or mortgage, banks set up between 1897 and 1902 to fill this gap were integral to Matsukata's policy of institutional specialization and constituted the last major component in Japan's achievement of financial transition by 1913. The two most important special bank initiatives were the Hypothec Bank of Japan (Nippon Kagyo Bank) organized in 1897 and a network of Agricultural and Industrial Banks. The former imitated France's Crédit Foncier while the Industrial Bank of Japan was modeled on the Crédit Mobilier. Like commercial banking in the 1870s and 1880s, the special banks relied substantially on an infant industry strategy of incentives and subsidies. The government guaranteed private investors purchasing stock in the new banks a dividend of $5 \%$ for ten years; controlled the banks' policy through the Ministry of Finance; and, using the pool of postal savings, absorbed a substantial part of the debenture issues which were the main source of the banks' capital. ${ }^{66}$

In Southeast Asia the provision of long-term finance varied between countries and followed the banking tradition of the ruling metropolitan power. Throughout the region long- 
term institutional finance for Asians, though not for Europeans, was virtually unavailable, even for primary commodity production or for agricultural improvements. Financial dualism of this kind, and an only patchy availability of long-term finance, reveal pre-World War II Southeast Asia as well short of financial transition.

Southeast Asian natural resource abundance shaped both economic and financial structure. In small primary production-oriented economies like Southeast Asia’s, rich natural resources and a lack of domestic market scale economies typically work together to delay industrialization, perhaps for lengthy periods. ${ }^{67}$ Factor endowments in Southeast Asia of abundant resources and virtually unlimited cheap labour, available through immigration from India and China and the traditional sectors of dual economies, made it efficient for small producers using only simple tools and traditional techniques to expand onto new land and continuously reproduce an earlier pattern of development. Until 1910 this was close to the sole method of expansion in vent-for-surplus agriculture and in Malayan tin mining. Such export expansion required little more than circulating or wage fund capital and was largely selffinancing. ${ }^{68}$ Export expansion like Southeast Asia’s, dependent chiefly on capital widening, sharply limited both the need for finance and pressure for financial innovation.

Southeast Asia differed fundamentally from Japan in that the financial institutions which did develop to facilitate long-term investment in primary production — the agency houses together with agricultural banks in Indonesia — served almost exclusively European enterprise and looked to metropolitan markets, especially London, as sources of capital. Thus, in Malaya, Asian entrepreneurs, mostly Chinese, who required loans to develop rubber estates, relied on 'very limited amounts' from European banks against security like house mortgages; credit came chiefly from storekeepers and Chettiar moneylenders. ${ }^{69}$ McKinnon terms the exclusion of Asians from formal finance 'financial repression': 'rubber estates in the Far East were developed by Europeans with overseas banking connections and access to direct finance ... 
Entrepreneurship in the indigenous economy was allowed to languish without significant financial support'. ${ }^{70}$

\section{Rural finance}

A developed financial system links urban and rural economic sectors. It raises productivity by transferring resources to higher yielding projects both within and between these sectors and, at the same time, through the transfer mechanism of financial intermediaries, contributes to the elimination of a dual economy. This section analyzes rural finance and the emergence of ruralurban financial linkages in Japan and Southeast Asia.

In Japan in 1885 only about 7\% of agricultural borrowings were from modern financial institutions, but by 1910 this proportion had risen to over a third and in 1932 to more than two fifths. ${ }^{71}$ Although this still left a large and vibrant informal rural financial sector, an ongoing process of financial unification was evident. Comparable statistics do not exist for Southeast Asia. It is clear, however, that few Asian farmers came in direct contact with modern finance.

Three reasons for differential rural financial development in Japan and Southeast Asia can be identified. One was that intersectoral financial linkages grew in Japan but only to a limited extent in Southeast Asia. In late nineteenth-century Japan, supply leading policies which made banking profitable led to an increase in the number of banks and branches such that by 1901 banking reached 'virtually every town'. ${ }^{72}$ Agriculture could draw extensively on bank finance, especially for the commercial crops of silk, tea and rice. ${ }^{73}$ Furthermore, the Nippon Kagyo Bank, along with its prefecture affiliates, actively financed agricultural improvements. Until 1900, agriculture was a net borrower from the banking system and the former rural elite net lenders to the banks. ${ }^{74}$ After the turn of the century, closely integrated Japanese rural and urban finance promoted structural change and economic growth through the transfer of agricultural surpluses to the industrial sector.

No rural banking network comparable to Japan's developed in Southeast Asia. European 
and local Asian banks remained concentrated in the main port cities. Local Asian banks, unlike the region's cultivators, were mainly ethnic Chinese and, furthermore, too newly established seriously to consider extending operations to rural areas. Dawson's Bank in Burma, with its head office in Pyapon and eight branches by 1929, was the principal instance of a Europeanowned bank in rural Southeast Asia. ${ }^{75}$

Second, there was a clear divergence between Japanese and Southeast Asia governments in their approach to rural finance. Until around 1900 the Japanese government's attitude towards financial provision in rural areas was laissez-faire. ${ }^{76}$ In 1900 , however, the Industrial Cooperatives Law led to the reorganization of existing cooperatives and the formation of many new ones to provide credit. Amendments to the Agricultural and Industrial Bank Law allowed up to five-year loans from the Agricultural and Industrial Banks to credit cooperatives. Furthermore, they could draw liberally on funds from the government's Deposit Bureau, which itself mainly tapped the postal saving system. Credit cooperatives grew rapidly until 1917, by which time deposits first began to exceed lendings. ${ }^{77}$

As in pre-1900 Japan, governments in Southeast Asia were little, if at all, involved in rural financial provision. ${ }^{78}$ That changed in the twentieth century as part of a growing interest in Asian welfare. But Southeast Asian governments, not driven by the strong political agenda of nationalist and modernization goals of the Japanese state, generally promoted cooperatives with far less enthusiasm, and certainly with fewer resources, than in Japan.

Third, differences in geographical and social settings help to explain contrasting Japanese and Southeast Asian rural finance. Government involvement, as in Japan, can help to establish rural cooperatives, but these ultimately depend on social organization, commitment and cultural attitudes. Plural societies and the frontier character of Southeast Asia's vent-for-surplus areas militated against cooperation. In Thailand's rice export areas, for example, many families made several moves in a lifetime; peasants 'who felt overwhelmed by debt dues and tax arrears 
disappeared in the middle of the night and sought out new land'. ${ }^{79}$ An exception was Java, where more settled communities and economies of scale associated with high population density created, as in Japan, characteristics consistent with an ethos of cooperation and with institutional finance achieving cost effectiveness. The Dutch built on these advantages with substantial efforts to establish credit facilities through networks of regulated pawnshops and village banks. ${ }^{80}$ But in 1939 in Southeast Asia as a whole, including Indonesia's Outer Provinces, Asian cultivators continued to rely almost entirely on informal finance from such sources as village storekeepers, moneylenders and rotating saving and credit associations.

\section{Findings and Discussion}

Financial transition in capitalist economies tends to divide into two phases. In an initial period, effective institutions are established, chiefly a unified reliable monetary standard, a critical mass of commercial banks, a central bank or its equivalent, and efficient fiscal arrangements. This first stage corresponds to what Sylla terms 'financial revolution'. ${ }^{81}$ In England this revolutionary phase occurred from about 1680 and 1720 and in the United States, with a remarkable burst under Alexander Hamilton when he was Treasury Secretary from 1789 to 1795 . Extraordinarily rapid United States' financial development continued through $1825{ }^{82}$

During the second period, substantial qualitative and quantitative change takes place. In part, this involves the maturing of existing institutions, and in part the emergence of a more varied range of financial intermediaries, especially those providing some form of long-term finance. Reflecting these changes, a country's financial system acquires depth. Financial assets increase relative to GNP, and M2 rises relative to both M0 and M1. In England, as Sylla shows,

a modern financial system emerged 'sometime in the nineteenth century'. ${ }^{83}$ This second phase in the United States, though held up by a Jeffersonian-Jacksonian political agenda, was perhaps shorter than in England but probably not fully accomplished until the 1880s. By the end of the second period, the financial structure resembles that of a developed country. 
Judged by this taxonomy, in Japan the years 1868 to 1885 correspond to the first stage of financial transition. By the end of the period Japan had a uniform currency based on the yen. A network of commercial banks, started largely in response to government fiscal incentives, operated. Beginning in 1886 the Bank of Japan functioned as a central bank. A strong fiscal system, dependent on state taxation of rice production, was an early priority of the Meiji government and essential to completion of the first stage of transition in Japan.

The second phase of Japan's financial transition corresponded in its inception in 1886 to the start of modern economic growth and ended in 1913. During this same period Japan assumed the features of a modern state. In the course of financial transition, commercial banks were unified into a single system with the expiry of the national bank licenses. Short-term credit became freely available. It was complemented by the rise of the Tokyo and Osaka stock markets and new long-term credit banks for agriculture and industry organized by the government between 1897 and 1902. Through the Bank of Japan the government achieved great influence over both commercial banks and the long-term credit banks which it partly owned. Adoption of the gold standard in 1897 enhanced Japan's scope to borrow internationally. Finance for the Russo-Japanese War expanded Japan's new financial infrastructure through extensive external and internal borrowing. Consistent with the timing of phases identified by Sylla, Goldsmith emphasizes that in just over five decades ending in 1913, Japan acquired a financial structure 'qualitatively and quantitatively not too dissimilar from ... those built up in contemporary Western countries in about twice to three times that time span'. ${ }^{84}$ Applying the two-stage taxonomy of financial transition to Southeast Asian countries, in 1939 even the most advanced had yet fully to complete the first stage and in important respects still fell short of the Japanese position of 1885. The establishment of uniform monetary standards, for the most part after 1900, was accomplished at the expense of an elastic money supply which could promote economic development. Financial institutions either were 
European-oriented or faced systemic uncertainty. The gold-exchange standard and currency board system exacerbated instability already present in the region's economies because of their dependence on a few export staples, and hindered the growth of local Asian banks. European exchange banks, interested mainly in financing foreign trade, dominated commercial banking. Unlike banks in Japan, which spread through the country, the exchange banks concentrated in the larger port cities. Long-term institutional finance for agriculture existed in various forms but served almost exclusively the European community. Financial repression in McKinnon's sense of a dual financial structure predominated. In 1939, rural areas and all but a few Asians still relied on a pre-modern financial structure of moneylenders, storekeepers and the like.

Four main considerations account for the differing speeds of financial transition in Southeast Asia and Japan. First, different man/land ratios and divergent natural resource bases influenced the speed of financial transition. As was true of Southeast Asia, '[F]inance', John Gurley remarks, 'is often handicapped by the narrow range of primary securities which emanate from equally narrow economic structures — one-crop economics, etc. ${ }^{, 85}$ In Southeast Asia's vent-for-surplus economies, abundant natural resources substituted for capital mobilized through financial institutions as an input to economic growth. Pressure for change in Southeast Asian countries was limited by a continued ability to tap natural resources, and attain generally acceptable economic growth levels without substantial changes in the technologies either of growing agriculture staples or of finance. The capacity of Southeast Asia's economies to achieve economic growth with relatively little state interference suited the predominantly liberal preferences of the region's colonial governments for free trade and recourse to the market. Financial development in Japan, by contrast, bears out Gerschenkron's predictions for latecomers: that some form of modern financial system is acquired at an accelerated pace; that government often takes the initiative in instigating this; and that the country borrows foreign techniques, as Japan so liberally did when setting up its financial institutions. ${ }^{86}$ 
Second, in Japan, much more than in Southeast Asia, continuous technological innovation and movement towards large-scale production created important new outlets for finance and investment. Principal objects for finance in pre-Meiji Japan were 'the deficits of aristocratic and rural overspenders, not exactly the right basis for a financial system linked to sustained economic growth'. ${ }^{87}$ Financial transition and modern economic growth go together because the technological basis of the latter creates major new opportunities for finance and the emergence of financial intermediaries. Investment opportunities thrown up by technological change encourage saving by creating a demand from entrepreneurs for finance and by raising returns available to savers. If the state, as in pre-Second World War Japan, promotes technological development through industrial policy and military activities, it also encourages financial development, even when not itself financing new projects.

A third reason, related to the first two, for relatively little financial development in Southeast Asia is that financing methods depend crucially on the distribution and nature of capital formation. Throughout rural Southeast Asia the role of formal finance was limited because, even with the spread after 1910 of European-owned estates able to draw on bank credit, exports still relied mainly on small, family-based production units. Although Meiji economic growth resembled Southeast Asia's in a dependence on small farmers, Japanese agriculture drew much more than Southeast Asian on funds from other sectors with a consequent expansion of the financial superstructure. And, unlike in Southeast Asia, there was considerable structural change in Japan's economy with the spread of modern industry and railways financed largely by domestic borrowing which required modern financial institutions. To a substantial extent the Japanese government, motivated by nationalism and a perceived threat of foreign domination, pushed forward the development of financial institutions ahead of demand, encapsulated in Patrick's concept of supply-leading finance. ${ }^{88}$ 
Accordingly, political considerations are the fourth, and most important, explanation for the differing speeds of financial transition. Although not citing Japan, Ferguson emphasizes the central role of politics in the emergence of modern financial systems. ${ }^{89}$ Financial modernity is fundamental to the creation of a modern state and to the political aims of enhancing military capabilities and expansionary nationalism. Realizing these aims, in turn, builds financial capacity. The financing of war, by drawing on a nation's financial infrastructure, expands it. Japan between 1868 and 1939 easily fits such a model. Japanese financial development cannot be understood other than as part of a politically inspired drive to modernisation and industrialisation.

Men do not make history independent of existing forces, and I have argued that in latenineteenth century Southeast Asia the absence of an effective political nationalism made financial transition highly unlikely. Even given a more advanced financial structure, it seems doubtful that Southeast Asia could have progressed too much further towards modern economic growth than it did: in Southeast Asia the restrictive features of colonialism worked against both economic development and financial transition. Financial development requires a permissive social and economic base, and is much helped, as Sylla observes, if not by war at least by some similar peacetime stimulus. ${ }^{90}$ There was, in pre-World War II Southeast Asia, no possibility of strongly government-led financial development like that in Singapore beginning in the 1970s. ${ }^{91}$

Some forms of colonial rule, as post-World War II Hong Kong shows, may be not merely compatible with financial development but aid it by ensuring stability and the rule of law. In pre-World War II Southeast Asia, however, colonialism probably significantly retarded financial development. The political disadvantages associated with colonial status in Southeast Asia made financial transition difficult. Colonial governments eschewed the mass participation and political integration of the modern state, as well as lacking its freedom to take political decisions. One of the principal lessons to be learnt from Japan is that financial transition can be 
accelerated; another, that a decision to do so is essentially political. If instead of emerging from semi-colonial status Japan had been colonized, its progress towards financial transition might have been much closer to Southeast Asia's.

From the perspective of Southeast Asia in 1929, and in light of comparatively high per capita incomes there over the previous 60 years, it might have appeared that Goldsmith was wrong in indicating a 'rough parallelism' between financial and economic development, and in maintaining that all countries follow a broadly similar path of financial transition. But by the post-World War II period when Southeast Asia gained independence, the relevance of Japanese financial transition between 1868 and 1913 was fully apparent. Japan's experience shows how transitions to financial development, modern economic growth and a modern state are, if not in any rigid causal relationship, part of a complementary process of political, economic and social change. After the Second World War, for Southeast Asia to continue to grow economically its constituent countries had to move from earlier natural-resource based, vent-for-surplus growth to follow Japan's example of multiple transitions. Significantly, Singapore and Malaysia, the closest to Japan at the end of the 1920s, were the first to do so. 
Table 1

Southeast Asian and Japan Per Capita GDP, 1870-1938

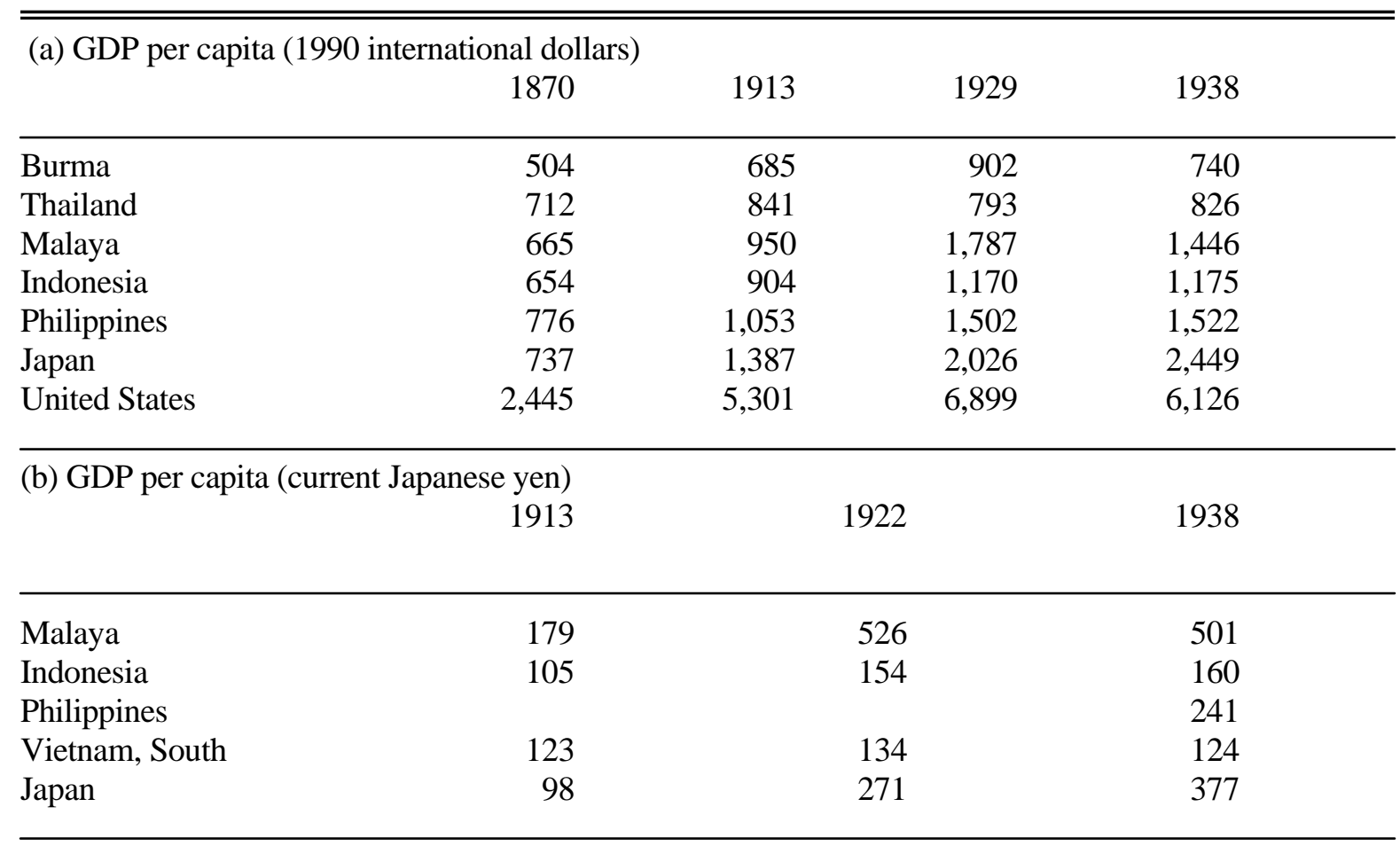

Notes:

1. In panel (c) the 1929 figure for Burma refers to 1931.

2. Malaya refers to the Malay Peninsula and Singapore, Penang and Malacca. Figures are the population weighted per capita incomes from Maddison. For 1929 and 1938 Maddison does not have estimates for Singapore. It is assumed that Singapore grew at the same rates as Malaysia (the Malay Peninsula and Penang).

Sources: A. Maddison, The world economy: historical statistics (Paris, 2003), pp. 87, 180-83; J-P. Bassino and P. van der Eng, ' Economic divergence in East Asia: new benchmark estimates of levels of wages and GDP, 1913 1970' processed, 2002), p. 12. 
Table 2

Southeast Asia, Japan and the United States: Measures of Money Supply, 1885-1938

(a) Ratio of commercial bank demand deposits to M0 (D/M0) and M0 per capita (1913 US\$)

1913

1929

1938

\begin{tabular}{rrrrrr}
\cline { 5 - 6 } D/M0 & $\begin{array}{r}\text { M0 } \\
\text { per } \\
\text { capita }\end{array}$ & D/MO & $\begin{array}{r}\text { M0 } \\
\text { per } \\
\text { capita }\end{array}$ & $\begin{array}{r}\text { D/M0 } \\
\text { M0 } \\
\text { per } \\
\text { capita }\end{array}$ \\
\hline- & - & - & - & 0.34 & 6.23 \\
- & 1.45 & - & 3.73 & - & 3.22 \\
- & 4.72 & - & 5.84 & 0.29 & 6.05 \\
0.22 & 9.19 & - & 12.16 & 1.02 & 18.89 \\
0.30 & 2.24 & 0.34 & 3.52 & 0.56 & 3.79 \\
1.56 & 6.13 & 0.49 & 4.42 & 0.36 & 10.10 \\
5.13 & 19.33 & 2.32 & 8.93 & 2.10 & 7.66 \\
& & 5.84 & 18.80 & 4.47 & 28.86 \\
\hline
\end{tabular}

(b) Ratios of monetary aggregates to GDP

1885

1900

1913

\begin{tabular}{|c|c|c|c|c|c|c|c|c|c|}
\hline & $\begin{array}{l}\text { MO/ } \\
\text { GDP }\end{array}$ & $\begin{array}{l}\text { M1/ } \\
\text { GDP }\end{array}$ & $\begin{array}{l}\text { M2/ } \\
\text { GDP }\end{array}$ & $\begin{array}{l}\text { M0/ } \\
\text { GDP }\end{array}$ & $\begin{array}{l}\text { M1/ } \\
\text { GDP }\end{array}$ & $\begin{array}{l}\text { M2 } \\
\text { GDP }\end{array}$ & $\begin{array}{l}\text { M0/ } \\
\text { GDP }\end{array}$ & $\begin{array}{l}\text { M1/ } \\
\text { GDP }\end{array}$ & $\begin{array}{l}\text { M2/ } \\
\text { GDP }\end{array}$ \\
\hline US & 0.11 & & 0.22 & 0.13 & & 0.32 & 0.09 & 0.33 & 0.45 \\
\hline Japan & 0.22 & 0.25 & 0.25 & 0.13 & 0.29 & 0.35 & 0.13 & 0.22 & 0.49 \\
\hline
\end{tabular}

(c) Ratios of monetary aggregates to GDP

1913

1929

1938

\begin{tabular}{|c|c|c|c|c|c|c|}
\hline M0/ & M1/ & M0/ & M1/ & M0/ & M1/ & M2/ \\
\hline GDP & GDP & GDP & GDP & GDP & GDP & GDP \\
\hline
\end{tabular}

\begin{tabular}{lrrrrrrr}
\hline Burma & 0.07 & - & 0.27 & - & 0.18 & 0.24 & 0.29 \\
Indochina & - & - & - & - & - & - & - \\
Thailand & 0.08 & - & 0.10 & - & 0.05 & 0.07 & 0.07 \\
Malaya & 0.06 & - & 0.05 & - & 0.09 & 0.18 & 0.23 \\
Indonesia & 0.08 & 0.09 & 0.09 & 0.12 & 0.08 & 0.12 & - \\
Philippines & 0.06 & 0.08 & 0.07 & 0.10 & 0.12 & 0.17 & 0.21 \\
Japan & 0.13 & 0.22 & 0.13 & 0.43 & 0.13 & 0.40 & 0.79 \\
US & 0.09 & 0.33 & 0.07 & 0.29 & 0.17 & 0.46 & 0.64 \\
\hline \hline
\end{tabular}

Notes and Sources: Money supply and money supply deflators: Money supply: Base money supply or the monetary base (M0) is defined as the sum of currency held by the public and currency held by banks as vault cash. The article distinguishes between M1, which is M0 plus demand or sight (checking) deposits with commercial banks; and M2 which also includes time deposits (fixed term and savings accounts). Sources for money supply statistics are: Burma: Tun Wai, Burma's currency, p. 114. The figures for 1938 are for 1938/39. Indochina: Annuaire Statistique 1913 a 1922, p. 157, 1943-1944, p. 287. Thailand: Kingdom of Thailand, Department of Commerce and Statistics, Statistical year book of the Kingdom of Siam [or Thailand], (Bangkok), 1920, p. 127, 1933-35, p. 353, 1937-38 and 1938-39, p. 331; B. R. Shenoy, 'The currency, banking, and exchange system in Thailand', IMF Staff Papers (1950), pp. 292, 295. Figures for M0 are for the fiscal year beginning the year given in the table, e.g. 1913-14 for 1913. For 1938 figures are for December 1939. Malaya: Straits Settlements, 'Working of the currency department', Straits Settlements annual reports, 1912-1937 (Singapore); Straits Settlements, 'Working 
of the Malayan Currency Commission', Straits Settlements Annual Report, II, 1938 (Singapore, 1939). For 1938 demand and time deposits are estimated by assuming that these were in the same ratios to M0 (1.02 and 0.52) as for 31 December 1955. Demand and time deposits for 1955 are from Bank of England Archives, OV 65/10, 'Banking statistics'. These estimates probably constitute an upper bound for M1 and M2 in 1938. Indonesia: J. T. M. van Laanen, Money and Banking, 1816-1940, published as Vol.6, Changing Economy in Indonesia (The Hague, 1980), pp. 71-77, lines 16, 22. Philippines: Philippines, Department of Finance, Annual Report of the Treasurer of the Philippine Islands (Manila) 1913, p. 13; 1920, p. 41, 1930, p. 117, 1939, p. 110; Philippines, Annual Report of the Bank Commissioner of the Philippine Islands (Manila), 1929, p. 8, 1938, p. 17. For 1913 demand deposits includes the categories current accounts and demand deposits. Of these, current accounts was very much the larger and may not strictly have constituted demand deposits. Japan: K. Asakura and C. Nishiyama (eds.), Nihon Keizai no Kaheiteki Bunseki [A Monetary Analysis and History of the Japanese Economy] (Tokyo, 1974), p. 823. United States: Friedman and Schwartz, Monetary history, pp. 708-15. Figures are the averages of the monthly averages. For 1913 the figures are for 1914 and the figure for demand deposits for the seven months beginning June. Deflators: Money supply for Southeast Asia was deflated to 1913 prices with the index derived from the reflator in van der Eng, Indonesian National Income except Thailand for which the deflator in M. Sompop, Economic development of Thailand, 1850-1950 (Groningen, 1989), p. 251 was used. These two indices agree closely with each other and with Lewis' tropical commodities index. For Japan and the United States the same deflator as for GDP was used for money supply. For Japan this was the consumer price index from Goldsmith, Financial development of Japan, pp. 73, 110; and for the United States the GNP implicit price index from U.S. Department of Commerce, Historical, part 1, p. 224. Gross domestic product: Burma: A. Hlaing, 'Trends of economic growth and income distribution in Burma, 1870-1940', Journal of the Burma Research Society, 47 (1964), p. 143. Figures are for Net National Product. For 1913 the figure is for 1911/12 and for 1929 it is for 1926/27. Thailand: Sompop, Economic development, p. 251. Malaya: van der Eng, Historical Estimates. These estimates for Peninsular Malaya exclude Singapore and are in 1960 Straits dollars. GDP to include Singapore is estimated by assuming that Singapore's GDP was 39.6\% of Peninsular Malaya's (the proportion in 1956) and reflating using the price relationships in W. A. Lewis, Aspects of tropical trade, 1883-1965 (Stockholm, 1969), pp. 49-50. GDP for Singapore in 1956 is from Oshima, 'Growth', p. 49, and for Peninsular Malaya from C-Y. Lim, Economic development of modern Malaya (Kuala Lumpur, 1967), p. 317. Indonesia: van der Eng, Indonesian National Income. Philippines: R. Hooley, 'American economic policy in the Philippines, 1902-1940: exploring a dark age in colonial statistics', Journal of Asian Economics 16 (2005), pp. 480-81. Japan: Ohkawa and Sinohara, Patterns, pp. 267-69. Figures are for GNP. United States: United States, U.S. Department of Commerce, Historical statistics of the United States colonial times to 1970 Part 1 (Washington, DC, 1970l, part 1, p. 224.

Table 3

Southeast Asia, Japan and the United States: commercial bank assets, 1938

\begin{tabular}{lcc}
\hline \hline & Assets as \% of GDP & Assets per capita US\$ \\
\hline Burma & 0.08 & 2.49 \\
Thailand & 0.06 & 5.09 \\
Malaya & 0.28 & 52.82 \\
Philippines & 0.08 & 12.23 \\
Japan & 1.03 & 123.72 \\
United States & 0.66 & 432.41 \\
\hline \hline
\end{tabular}

Notes and Sources: As for table 2 and Burma: Tun Wai, Burma's currency, p. 195. Thailand: Shenoy, 'Currency', p. 295. Malaya: Bank of England Archives OV65/10, 'Banking statistics' and for GNP International Bank for Reconstruction and Development, The economic development of Malaya (Washington, DC, 1955), p. 509. Figures refer to 1949. Philippines: Philippines, Bureau of the Census and Statistics, Yearbook of Philippine statistics 1940. (Manila, 1941), p. 169. Japan: Goldsmith, Financial development of Japan, p. 54. Figures refer to 1940. United States: Friedman and Schwartz, Monetary history, p. 450. Exchange Rates: P. van der Eng, The silver standard and Asia's integration into the world economy (Canberra: Australian National University, Department of Economic History, working paper no.175, 1993), pp. 28-29. 


\section{References}

${ }^{1}$ R. W. Goldsmith, The financial development of India, Japan, and the United States (New Haven, 1983), pp. 1-2, 69 and The financial development of Japan, 1868-1977 (New Haven, 1983), pp. 69-69. Others have termed 'path' what I refer to here as 'pattern'. For example, see J. G. Gurley, 'Financial structures in developing countries', in D. Kirvine (ed.), Fiscal and monetary problems in developing states (New York, 1967), pp. 10816. On modern economic growth, see S. Kuznets, 'Modern economic growth: findings and reflections', American Economic Review, 63 (1973).

2 Goldsmith, financial development of India, Japan, and the United States, p. 4.

${ }^{3}$ Goldsmith, financial development of India, Japan, and the United States, p. 4.

${ }^{4}$ R. G. King and R. Levine, ' Finance and growth: Schumpeter might be right', Quarterly Journal of Economics, 108 (1993); R. Levine, 'Financial development and economic growth', Journal of EconomicLiterature,35 (1997); P. L. Rousseau and R. Sylla, 'Financial systems, economic growth, and globalization', in M. D. Bordo, A. M. Taylor and J. G. Williamson (eds.) Globalization in historical perspective (Chicago, 2003) and 'Emerging financial markets and early US growth', Explorations in Economic History 42 (2005).

${ }^{5}$ R. G. Rajan and L. Zingales, 'The great reversals: the politics of financial development in the $20^{\text {th }}$ Century', Journal of Financial Economics 69 (2003).

${ }^{6}$ Goldsmith, Financial development of India, Japan, p. 1.

7 This argument for comparing Southeast Asia with Japan draws on C. Geertz, Agricultural involution: the process of ecological change in Indonesia (Berkeley, 1963), pp. 124-54.

${ }^{8}$ R. Sylla, 'Financial systems and economic modernization', Journal of Economic History, 62 (2002).

${ }^{9}$ A. Iriye, 'Japan's drive to great power status' in M. P. Jansen (ed.), The Cambridge history of Japan, vol. 5 The nineteenth century (Cambridge, 1989), p. 749.

${ }^{10}$ W. G. Beasley, 'The foreign threat and the opening of the ports' in M. P. Jansen (ed.), The Cambridge History of Japan, vol. 5 The Nineteenth Century (Cambridge, 1989), pp. 306-7.

11 On traditional Japanese finance, see E. S. Crawcour and K. Yamamura, 'The Tokugawa monetary system', Economic Development and Cultural Change 18, part 1 (1970); E. S Crawcour, 'Industrialization and technological change', in K. Yamamura (ed.), The economic emergence of modern Japan (Cambridge, 1997), p. 58; R. P. Toby,' Both a borrower and a lender be: from village moneylender to rural banker in the Tempo era', Monumenta Nipponica 46 (1991); Y. Yasuba, ' The Tokugawa legacy: a survey', Economic Studies Quarterly, 38 (1987). On Japanese social capability, see K. Ohkawa and H. Rosovsky, Japanese economic growth (Stanford, 1973), p. 7.

${ }^{12}$ M. P. Jansen, ' Tokugawa and modern Japan', Japan Quarterly, 12 (1965), p. 36; see also Iriye, 'Japan's drive', pp. 728-29.

${ }^{13}$ S. Garon, ' Rethinking modernization and modernity in Japanese history: a focus on state-society relations', Journal of Asian Studies 53 (1994), p. 350 and see N. Nakamura, ' Meiji-era industrialization and provincial vitality: the significance of the first enterprise boom of the 1880s', Social Science Japan Journal 3 (2000).

${ }^{14}$ M. Maruyama, Thought and behaviour in modern Japanese politics (London, 1963), p. 97.

${ }^{15}$ For discussion of the modern state, see Iriye, 'Japan's drive'.

${ }^{16}$ Rosovsky, "'Lessons" of Japanese economic history', p. 234.

${ }^{17}$ K. Ohkawa and M. Shinohara, Patterns of Japanese economic development: a quantitative appraisal (New Haven, 1979), p. 278

${ }^{18}$ Ohkawa and Rosovsky, Japanese economic growth, pp. 81-84.

${ }^{19}$ Ohkawa and Shinohara, Patterns, pp. 280, 393.

${ }^{20}$ Goldsmith, Financial development of Japan, p. 35.

${ }^{21}$ Goldsmith, Financial development of Japan, p. 36; and see M. Metzler, Lever of empire: the international gold standard and the crisis of liberalism in prewar Japan (Berkeley, 2006), pp. 45-50, 68-69.

${ }^{22}$ Rosovsky, ' Japan's Transition to Modern Economic Growth, 1868-1885', in H. Rosovsky (ed.), Industrialization in two systems (New York, 1966), p. 92.

${ }^{23}$ See, for example, J. Shepherd, Industry in Southeast Asia (New York, 1941), p. 133 and passim.

${ }^{24}$ The argument that Japan had a much higher standard of living than per capita GDP alone suggests has been convincingly refuted by Maddison. See S. Hanley, ' A high standard of living in nineteenth century Japan: a fact or fantasy?', Journal of Economic History 43 (1983) and Everyday Things in Premodern Japan (Berkeley, 1997);A. Maddison, 'Review of Hanley, Everyday Things', Journal of the Japanese and International Economies, 13 (1999).

${ }^{25}$ Bank of Japan, Supplement to Hundred Year Statistics of the Japanese Economy - English Translation of Explanatory Notes (Tokyo, n.d.)., pp. 91-95; and see T. Yoshino, ' The creation of the Bank of Japan - its western origin and adaptation', Developing Economies 15 (1977), pp. 395-96.

${ }^{26}$ F. H. H. King , Money in British East Asia (London, 1957), p. 10; P. J. Drake, Currency, credit and 
commerce: early growth in Southeast Asia (Aldershot, 2004), pp. 92-97.

${ }^{27}$ C.Robequain, The economic development of French Indo-China (London, 1944), pp. 141-50; A. J. Schwartz, 'Currency boards: their past, present, and possible future role', Carnegie-Rochester Conference Series and Public Policy, 39 (1993), p. 167.

${ }^{28}$ Schwartz, 'Currency Boards', pp. 164-67; J. C. Ingram, Economic change in Thailand 1850-1970 (Stanford, 1971), pp. 152-62; G. H. A. Prince, ' Monetary policy in colonial Indonesia and the position of the Java Bank', in J. T. Lindblad (ed.), Historical foundations of a national economy in Indonesia, 1890s-1990s (Amsterdam, 1996), pp. 59-68; A. I. Bloomfield, Monetary policy under the international gold standard (New York, 1959), p. 14.

${ }^{29}$ J. M. Keynes, Collected writings. vol. 1 Indian currency and finance (London, 1971), pp. 24-25; Bloomfield , Monetary Policy, p. 14; U Tun Wai, Burma's currency and credit (Bombay, 1962), pp. 88-90.

${ }^{30}$ J. T. M. van Laanen , ' Between the Java Bank and the Chinese moneylender: banking and credit in colonial Indonesia', in A. Booth, W. J. O'Malley and A. Weidemann (eds.), Indonesian economic history in the Dutch colonial era (New Haven, 1990), p. 252; Prince, 'Monetary Policy'.

${ }^{31}$ See, for example, Straits Settlements, 'Currency Note Issue', Straits Settlements Annual Report, 1903 (Singapore, 1903), p. 19; Philippines, Division of Currency, Annual report of the Chief of the Division of the Currency, 1904 (Manila, 1904, pp. 11-19; Philippines, Secretary of Finance and Justice, Third Annual Report 1904, pp. 22-24.

${ }^{32}$ K. Sakurai, Financial aspects of economic development in Japan 1868-1958 (Tokyo, 1964), pp. 16-23.

${ }^{33}$ T. C. Smith, Political change and industrial development in Japan (Stanford, 1955), pp. 36-37.

${ }^{34}$ Bloomfield, Monetary policy, p. 14; M. Friedman and A. J. Schwartz, A monetary history of the United States, 1867-1960 (Princeton, 1971), p. 359.

${ }^{35}$ N. Tamaki, Japanese banking: a history, 1859-1959 (Cambridge, 1995), p. 17.

${ }^{36}$ H. Patrick, 'Japan 1868-1914', in R. Cameron, et al. (eds.), Banking in the early stages of industrialization (New York, 1967), pp. 264-65; Tamaki, Japanese banking, p. 76.

${ }^{37}$ Goldsmith, Financial development of Japan, p. 48.

${ }^{38}$ Goldsmith, Financial development of Japan, pp. 49-50; Tamaki, Japanese banking, pp. 104-6.

${ }^{39}$ Rousseau and Sylla, 'Emerging financial markets'; P. L. Rousseau, 'Finance, investment, and growth in Meijiera Japan', Japan and the World Economy 11 (1999).

${ }^{40}$ K. Yamamura, ' Japan 1868-1930: a revised view', in R. Cameron, et al. (eds.), Banking and economic development (New York, 1972), pp. 168-73; T. Nakamura, Economic growth in prewar Japan (New Haven, 1983) and Lectures on modern Japanese economic history 1926-1994 (Tokyo, 1994).

${ }^{41}$ Goldsmith, Financial development of Japan, p. 83; S. Asajima, 'Characteristics of the Japanese financial system during the inter-war period' and J. Hashimoto, 'Japanese industrial enterprises and the financial market between the two world wars', both in P. L. Cottrell, A. Teichova and T. Yuzawa (eds.), Finance in the age of the corporate economy, (Aldershot, 1997); Patrick, 'Japan', p. 253; Sakurai, Financial aspects, pp. 115-21, 140.

${ }^{42}$ HSBC Group Archive, LII, 121 and 122, Inspectors reports for Rangoon, Bangkok, Singapore, Batavia and Saigon; H. P. Willis, 'The Philippine National Bank', Journal of Political Economy 25 (1917), p. 410.

${ }^{43}$ Straits Settlements, Reports of the commissions on trade depression and the extension of credit facilities (Singapore, 1921), appx. 1, pp. 169-70, 174-77; Straits Settlements, Report of the commission to report on the trade of the Colony, 5 vols. (Singapore, 1934), III, pp. 415-17, 423, IV, p. 414; Burma, Report of the Burma provincial banking enquiry committee, 1929-30, 3 vols. (Rangoon, 1930), I, pp. 36, 42; M. J. Murray, The development of capitalism in colonial Indochina (1870-1940) (Berkeley, 1980), pp. 115, 132-33.

${ }^{44}$ See, for example, HSBC Group Archive, LII, 121, Inspectors Report Singapore 1924, 7, 9, 12, 17, 19-20, 26, 31, 33 and in LII, 120 Inspectors Report Batavia 1924, 20-21; Inspectors Report Bangkok 1924, 6; Inspectors Report Saigon 1924, 12-14. On lending to Chettiars and other Indians in Burma, see Burma, Banking Enquiry Committee, I, pp. 40-41, 215-18.

${ }^{45}$ N. Tamaki, 'The Yokohama Specie Bank; a multinational in the Japanese interest 1879-1931', in G. Jones (ed.), Banks as multinationals (London, 1990), p. 191.

${ }^{46}$ K. Ishii, ' Japanese foreign trade and the Yokohama Specie Bank, 1880-1913', in O. Checkland, S. Nishimura and N. Tamaki (eds.), Pacific banking, 1859-1959, (London, 1994); Patrick, 'Japan'; W. D. Wray, 'Japan's big three service enterprises in China, 1896-1936', in P. Duss, R. H. Myers and M. R. Peattie (eds.), The Japanese informal empire in China, 1895-1937, (Princeton, 1989), p. 38; M. Fletcher, "'The Japan Spinners Association: creating industrial policy in Meiji Japan', Journal of Japanese Studies, 22 (1996), pp.73-74.

${ }^{47}$ P. G. Yap, Scholar, banker, gentleman soldier: the reminiscences of Dr. Yap Pheng Geck (Singapore, 1982), p. 36, and see 28; 37-38. On Chinese banks in Indochina, see P. Brocheux and D. Hémery, Indochine la colonisation ambiguë (1858 - 1954) (Paris, 1995), p. 134.

${ }^{48}$ K-C. Wong, The Chinese in the Philippine economy 1898 - 1941 (Manila, 1999), p. 131; Burma, Banking enquiry committee, I, p. 44.

${ }^{49}$ Straits Settlements, Report of the commission on trade, III, p. 416; D. L. Grove and J. Exter, 'The Philippine 
Central Bank Act', Federal Reserve Bulletin, 34 (1948), p. 939; Bank of England Archives, OV65/10

Memorandum on the Oversea Chinese Banking Corporation.

${ }^{50}$ K. Ishii, ' Japan', in R. Cameron and V. I. Bovykin (eds.), International Banking 1870-1914, (New York, 1991), p. 227 and see 222-23; S. Yabushita and A. Inque, 'The stability of the Japanese banking system', Journal of the Japanese and International Economies 7 (1993), p. 390.

${ }^{51}$ Tamaki, Japanese banking, pp. 66, 135 and see K. Sugiyama, ' Business finance in Japanese business history', Japanese Yearbook on Business History 1 (1984), pp. 25-29; J. Hashimoto, ' How and when Japanese economic and enterprise systems were formed', Japanese Yearbook on Business History 13 (1996), pp. 13-14.

52 R. Sylla, 'Schumpeter redux: a review of Raghuram G. Rajan and Luigi Zingales 'Saving capitalism from the capitalists', Journal of Economic Literature 44 (2006), p. 401. It has been argued that by 1900, and progressively thereafter, the value of traded stocks on the two exchanges as a percentage of GDP placed Japan within the range of modern advanced economies. Y. Miwa and J. M. Ramseyer, 'Banks and economic growth: implications from Japanese history’, Journal of Law and Economics, 45 (2002), p. 140.

${ }^{53}$ United Nations, Mobilization of domestic capital in certain countries of Asia and the Far East (Bangkok, 1951), p. 192; Burma, Banking enquiry committee, I, p. 287.

${ }^{54}$ Crawcour, 'Industrialization', p. 59.

${ }^{55}$ Ishii, 'Japan', p. 215; K. E. Calder, ' Linking welfare and the developmental state: postal savings in Japan', Journal of Japanese Studies, 16 (1990), p. 38.

${ }^{56}$ S. J. Ericson, ' Private railroads in the Meiji Era: forerunners of modern Japanese management?', in Tsunehiko Yui and Keiichiro Nakagawa, (eds.), Japanese management in historical perspective (Tokyo, 1989), p. 506.

${ }^{57}$ Hashimoto, 'Japanese industrial enterprises', p. 100.

58 Tamaki, Japanese banking, pp. 66-67; Ericson, Sound, pp. 178-82.

59 Miwa and Ramseyer, 'Banks and economic growth'.

60 Tamaki, Japanese banking, p. 67 and see p. 136; Goldsmith, Financial development of Japan, p. 69.

${ }^{61}$ S. J. Ericson, The sound of the whistle: railroads and the state in Meiji Japan (Cambridge, MA, 1996). pp. 359-61.

${ }^{62}$ Quoted in Ericson, Sound, pp. 362-63.

63 Ericson, Sound, pp. 359-73.

${ }^{64}$ Calder, 'Linking Welfare', p. 39.

${ }^{65}$ P. H. Kuwayama, 'Postal banking in the United States and Japan: a comparative analysis', Monetary and Economic Studies, 18 (2000), p. 93.

${ }^{66}$ Goldsmith, Financial development of Japan, p. 51; Asajima, 'Characteristics'; S. Saito, 'The Industrial Bank of Japan during the inter-war period', in P. L. Cottrell, A. Teichova and T. Yuzawa, (eds.), Finance in the age of the corporate economy (Aldershot, 1997).

${ }^{67}$ H. Chenery and L. Taylor, 'Development patterns: among countries over time', Review of Economics and Statistics, 50 (1968), pp. 400-16.

${ }^{68}$ G. Huff, 'Globalization, natural resources and foreign investment: a view from the resource rich tropics', Oxford Economic Papers, 59, 5 (2007); G. Huff and G. Caggiano, 'Globalization, immigration, and Lewisian elastic labor in pre-World War II Southeast Asia’, Journal of Economic History, 67, 1 (2007), pp. 33-68.

${ }^{69} \mathrm{~J}$. W. F. Rowe, Studies in the artificial control of raw material supplies, no.2 rubber (London, 1931), pp. 1718; see also P. Brocheux, The Mekong Delta: ecology, economy and revolution, 1860-1960 (Madison, WI, 1995), p. 233, n. 72.

${ }^{70}$ R. I. McKinnon, Money and capital in economic development (Washington, DC, 1973), p. 70.

${ }^{71}$ Patrick, ' Japanese financial development in historical perspective, 1868-1980' in G. Ranis, et al. (eds.), Comparative development perspectives (Boulder, CO, 1984), p. 311; J. Teranishi, ' Financial system and the industrialization of Japan: 1900-1970', Banca Nazionale del Lavoro Quarterly Review, no. 174 (1990), p. 316.

72 J. Teranishi , 'Government credit to the banking sector: rural banks in nineteenth century Japan and the postwar Philippines', in K. Ohkawa and G. Ranis (eds.), Japan and the developing countries (Oxford, 1985), p. 295. On supply-leading finance in the development of banking, see H. Patrick, ' Financial development and economic growth in underdeveloped countries', Economic Development and Cultural Change, 14 (1966), pp. 175-77.

73 Patrick, 'Japan', p. 267.

${ }^{74}$ Teranishi , 'Government credit', pp. 301-3.

${ }^{75}$ Burma , Banking enquiry committee, I, pp. 44-45; Tun Wai, Burma's currency, pp. 74-75.

${ }^{76}$ A. Waswo, ' The transformation of rural society, 1900-1950', in P. Duus (ed.), The Cambridge history of Japan, vol. 6 The twentieth century, (Cambridge, 1988), p. 574.

${ }_{77}$ Bank of Japan, Supplement, pp. 120-21.

${ }^{78}$ R. E. Elson, The end of the peasantry in Southeast Asia (London, 1997), p. 200. 
${ }^{79}$ P. Phongpaichit and C. Baker, Thailand: Economy and Politics (Oxford, 1995), pp. 32, 21.

${ }^{80}$ P. van der Eng , Agricultural Growth in Indonesia (London, 1996), pp. 131-33.

${ }^{81}$ Sylla, 'Financial systems', pp. 281-88; see also R. Sylla, 'Emerging markets in history: the United States, Japan and Argentina', in R. Sato, et al. (eds.) Global Competition and Integration, (Boston, 1999), pp. 432-34, 435-38. For a critical view of the argument for financial revolution, see Y. Miwa and J. M. Ramseyer, 'Japanese industrial finance at the close of the 19th century: trade credit and financial intermediation', Explorations in Economic History 43 (2006).

82 Rousseau and Sylla, 'Emerging financial markets'.

${ }^{83}$ Sylla, 'Financial Systems', p. 281.

${ }^{84}$ Goldsmith, Financial development of Japan, p. 69.

85 Gurley, 'Financial structures', p. 111.

86 A. Gerschenkron, Economic backwardness in historical perspective (Cambridge, MA, 1966), pp. 32-34, 4549.

${ }^{87}$ Goldsmith, Financial development of Japan, p. 7. In Tokugawa Japan the elite of samurai, daimyo and the shogunate absorbed nearly a quarter of GDP. A. Maddison, The world economy: a millennial perspective (Paris, 2001), p. 258.

88 Patrick, ' Financial development and economic growth', pp. 175-77.

${ }^{89}$ N. Ferguson, The cash nexus (New York, 2001) pp. 12-20, 420-21.

90 Sylla, 'Schumpeter redux', p. 397.

${ }^{91}$ W. G. Huff, 'What is the Singapore model of economic development?', Cambridge Journal of Economics, 19 (1995), pp. 750-52. 